\title{
Mechanisms of Resistance in Gram-Negative Urinary Pathogens: From Country-Specific Molecular Insights to Global Clinical Relevance
}

\author{
Branka Bedenić ${ }^{1,2}$ and Tomislav Meštrović ${ }^{3,4, *}$ \\ 1 Department of Clinical and Molecular Microbiology, University Hospital Centre Zagreb, \\ 10000 Zagreb, Croatia; branka.bedenic@kbc-zagreb.hr or branka.bedenic@mef.hr \\ 2 Department of Medical Microbiology and Parasitology, School of Medicine, University of Zagreb, \\ 10000 Zagreb, Croatia \\ 3 Clinical Microbiology and Parasitology Unit, Dr. Zora Profozić Polyclinic, 10000 Zagreb, Croatia \\ 4 University Centre Varaždin, University North, 42000 Varaždin, Croatia \\ * Correspondence: tmestrovic@unin.hr
}

Citation: Bedenić, B.; Meštrović, T. Mechanisms of Resistance in Gram-Negative Urinary Pathogens: From Country-Specific Molecular Insights to Global Clinical Relevance. Diagnostics 2021, 11, 800. https:// doi.org/10.3390/diagnostics11050800

Academic Editor: Pierfrancesco Francesco Bassi

Received: 1 February 2021

Accepted: 26 April 2021

Published: 28 April 2021

Publisher's Note: MDPI stays neutral with regard to jurisdictional claims in published maps and institutional affiliations.

Copyright: (c) 2021 by the authors. Licensee MDPI, Basel, Switzerland. This article is an open access article distributed under the terms and conditions of the Creative Commons Attribution (CC BY) license (https:// creativecommons.org/licenses/by/ $4.0 /)$.
Abstract: Urinary tract infections (UTIs) are the most frequent hospital infections and among the most commonly observed community acquired infections. Alongside their clinical importance, they are notorious because the pathogens that cause them are prone to acquiring various resistance determinants, including extended-spectrum beta-lactamases (ESBL); plasmid-encoded AmpC $\beta$-lactamases ( $\mathrm{p}$-AmpC); carbapenemases belonging to class A, B, and D; qnr genes encoding reduced susceptibility to fluoroquinolones; as well as genes encoding enzymes that hydrolyse aminoglycosides. In Escherichia coli and Klebsiella pneumoniae, the dominant resistance mechanisms are ESBLs belonging to the CTX-M, TEM, and SHV families; $\mathrm{p}-\mathrm{AmpC}$; and (more recently) carbapenemases belonging to classes A, B, and D. Urinary Pseudomonas aeruginosa isolates harbour metallo-beta-lactamases (MBLs) and ESBLs belonging to PER and GES families, while carbapenemases of class D are found in urinary Acinetobacter baumannii isolates. The identification of resistance mechanisms in routine diagnostic practice is primarily based on phenotypic tests for the detection of beta-lactamases, such as the double-disk synergy test or Hodge test, while polymerase chain reaction (PCR) for the detection of resistance genes is mostly pursued in reference laboratories for research purposes. As the emergence of drug-resistant bacterial strains poses serious challenges in the management of UTIs, this review aimed to appraise mechanisms of resistance in relevant Gram-negative urinary pathogens, to provide a detailed map of resistance determinants in Croatia and the world, and to discuss the implications of these resistance traits on diagnostic approaches. We summarized a sundry of different resistance mechanisms among urinary isolates and showed how their prevalence highly depends on the local epidemiological context, highlighting the need for tailored interventions in the field of antimicrobial stewardship.

Keywords: urinary tract infections; UTI; gram-negative bacteria; antibiotics; antimicrobial drugs; resistance mechanisms; molecular diagnostics; microbiology

\section{Urinary Tract Infections: Introduction, Epidemiology, Pathophysiology, and Pathogen Profile}

Urinary tract infections (UTIs) are the most frequent hospital infections, and second among community acquired infections after respiratory tract infections, affecting hundreds of millions of individuals every year [1]. These infections can be distressing and, in certain instances, even life threatening, with both females (40\%) and males (12\%) reporting at least one symptomatic urinary tract infection (UTI) during their lives [2]. UTIs develop as a result of the presence and multiplication of microorganisms in the different parts of the urinary system, subsequently resulting in tissue invasion, inflammatory response, and various symptoms depending on the localization of the infection [3]. Urine is considered a primary 
sterile body fluid; however, it can easily get contaminated with microorganisms stemming from the urethra, perineum, or vagina, while newer studies challenge this paradigm as the presence of a urinary microbiome is being recognized [4]. The protection against UTI is based on normal urine flow, low $\mathrm{pH}$, and high osmolality preventing replication of potential pathogens that can cause disease [3]. Intrinsic protective factors include mucus immunoglobulin A (IgA) antibodies, cytokine, and chemokine production [5].

Risk factors for the development of UTI comprise gender, age, the presence of urinary catheters, pregnancy, vesicoureteral reflux, urinary incontinence, immunosuppression, hospitalization, and organ transplantation [6,7]. Uropathogenic bacteria possess a plethora of virulence factors involved in the pathogenesis (type I pili, type III pili, alginate, haemolysins, aerobactin, siderophores), but they primarily utilize fimbriae to mediate the attachment to the urinary epithelium and subsequent penetration [3,7]. Following this initial step, the pathogens can migrate to the kidney (by using flagella) and cause pyelonephritis [8]. In the outpatient setting, UTIs usually arise due to the ascendant spread of endogenic microbiota from the intestines. Consequently, among adults, they are more frequently observed among woman due to shorter urethra, whereas in men UTIs are usually considered complicated and linked to prostatic hypertrophy or adenoma [8]. Conversely, UTIs in the hospital setting are usually associated with urinary catheters, with the source of infection being intestinal microbiota or contaminated hands of the hospital staff [9]. In older populations urinary catheters are important risk factors for UTIs, particularly in long-term care facilities [9]. UTIs in children are most frequently associated with urinary tract abnormalities such as vesicoureteral reflux [10]. According to the guidelines, UTIs can be classified as acute uncomplicated cystitis in woman, acute uncomplicated pyelonephritis, complicated urinary tract infections in men, asymptomatic bacteriuria, and recurrent UTIs [9].

Acute UTIs are associated with a large number of bacterial agents $\left(>10^{5}\right.$ colonyforming units per millilitre or $\mathrm{CFU} / \mathrm{mL}$ ), whereas lower numbers are usually due to contamination with intestinal microbiota [11]. For that reason, urine culture is pursued as a quantitative method based on determination of bacterial count, and the role of the clinical microbiologist is to distinguish between true bacteriuria and contamination. According to the current guidelines [9,12], in acute, uncomplicated cystitis, urine culture is not necessary, as the diagnosis is established on the basis of urine sediment examination or a leukocyte esterase test. Acute uncomplicated pyelonephritis is confirmed by urine culture $\left(\geq 10^{4} \mathrm{CFU} / \mathrm{mL}\right.$ in pure culture) and urinary sediment analysis. Complicated urinary tract infections are diagnosed based on leukocyte esterase and urine culture with $\geq 10^{4} \mathrm{CFU} / \mathrm{mL}$, except in pregnancy when the lower CFU is also considered significant $\left(\geq 10^{3} \mathrm{CFU} / \mathrm{mL}\right)$ [12]. Asymptomatic bacteriuria in women is characterized by $\geq 10^{5} \mathrm{CFU} / \mathrm{mL}$ in pure culture in two consecutive midstream urine cultures taken $24 \mathrm{~h}$ apart; conversely, in men it is sufficient to obtain one urine culture. In recurrent cystitis the breakpoint is $\geq 10^{3} \mathrm{CFU} / \mathrm{mL}$ in pure culture, whereas in pyelonephritis it is $\geq 10^{4} \mathrm{CFU} / \mathrm{mL}[9,12]$.

Primary urinary pathogens are Escherichia coli (E. coli) and Staphylococcus saprophyticus (S. saprophyticus), responsible for $80 \%$ of UTIs in healthy individuals $[13,14]$. Secondary pathogens are principally Gram-negative species such as Enterobacter spp., Klebsiella spp., Proteus mirabilis (P. mirabilis), Morganella morganii (M. morganii), Citrobacter spp., Serratia spp., Pseudomonas aeruginosa (P. aeruginosa), and Acinetobacter baumannii (A. baumannii) $[9,13,14]$. Among Gram-positive species, Enterococcus spp. and Stapyhlococcus aureus are categorized as secondary pathogens $[9,15]$. The whole group of secondary pathogens is rarely observed in uncomplicated UTIs, but are frequently isolated in complicated urinary tract infections, as well as from hospitalized patients [16]. For Streptococcus agalactiae (S. agalactiae), Stenotrophomonas maltophilia, Burkholderia cepacia, and yeasts, there is no adequate evidence at the moment regarding their pathogenicity, albeit they are potentially deemed important when isolated in large numbers and in repeated urine samples. Furthermore, S. agalactiae can be considered an important pathogen in pregnant woman and patients suffering from diabetes mellitus, while alpha-haemolytic streptococci, lactobacilli, diphtheroids, and Gardnerella vaginalis belong to the urogenital microbiota [4,15]. 
Nonetheless, the emergence of drug-resistant bacterial strains in the management of UTIs represents one of the most pertinent public health issues of the modern era [1]. This review aims to appraise mechanisms of resistance in Gram-negative urinary pathogens, provide a detailed map of resistance determinants in Croatia and put it within the global context for all relevant Gram-negative pathogens, and to discuss the implications of these resistance traits on clinical approaches and the choice of antimicrobial drugs.

\section{The Evolving Story of Resistance Determinants}

As already mentioned, antimicrobial resistance in the urinary pathogens is increasingly being observed, primarily as a result of our choices regarding antimicrobial treatment. It commonly occurs as a result of target alteration, diminished drug accumulation, and drug modification [14]. Accordingly, the most pertinent resistance determinants found among urinary tract pathogens are extended-spectrum beta-lactamases (ESBL), plasmid-mediated AmpC beta-lactamases, carbapenemases, and reduced susceptibility to fluoroquinolones due to the acquisition of $q n r$ genes $[7,14]$.

The first extended-spectrum beta-lactamase (ESBL) was SHV-2 described in Germany in 1983 in Klebsiella oxytoca [17]. Following that discovery, the spread of ESBL-positive Enterobacteriaceae initially occurred throughout Europe and later all over the world. Today, they are the most frequent among hospital isolates of K. pneumoniae and E. coli, but they have also been reported among community isolates of Enterobacteriaceae [18]. The majority of ESBLs belong to three families: TEM (Temoneira), SHV (sulfhydryl variable), and CTXM (cefotaximase). TEM and SHV variants are dominant among hospital isolates, while CTX-M variants are typical for community isolates [14]. Moreover, TEM and SHV variants are derived by mutations of parental broad spectrum TEM-1, TEM-2, and SHV-1 betalactamases [18]. CTX-M beta-lactamases are a growing family of plasmid-encoded ESBLs that preferentially hydrolyse the antimicrobial agent cefotaxime. They are not closely related to TEM or SHV beta-lactamases, but they are typical members of Ambler's class A derived from the Gram-negative bacterial genus Kluyvera [19].

In contrast to TEM and SHV beta-lactamases, which rely on amino acid substitutions to extend their substrate profile, CTX-M enzymes have an intrinsic extended-spectrum profile [20]. Furthermore, contrary to TEM and SHV enzymes, which are usually associated with hospital pathogens, CTX-M are predominantly isolated from community acquired infections [21]. CTX-M beta-lactamases are the dominant type of ESBLs in many countries of the world such as the United Kingdom, Italy, Spain, Greece, Poland, Bulgaria, Russia, Latvia, Brazil, China, Taiwan, and many others [21-23]. There are also rare types of ESBLs such as VEB, PER, or IBC [18]. Genes encoding ESBLs are almost always located on a transferable plasmid, which often contains genes for aminoglycoside, tetracycline, sulphonamide, and fluoroquinolone resistance [18]. Furthermore, ESBL-producing Enterobacteriaceae strains can cause outbreaks of nosocomial infections [24-26], which are rather difficult to control due to their multiresistant phenotype [27].

Plasmid-mediated AmpC beta-lactamases are derived from the chromosomal betalactamases of the bacteria belonging to the genera Enterobacter, Serratia, Citrobacter, Pseudomonas, and Acinetobacter by the escape of the chromosomal gene to a plasmid $[14,19,28]$. They hydrolyse third generation cephalosporins, monobactams, and cephamycins but spare fourth generation cephalosporins and carbapenems. Unlike ESBLs, they are not susceptible to inhibition with clavulanic acid, sulbactam, or tazobactam $[19,28]$.

Carbapenems are often considered as "the last resort antibiotics" for the treatment of severe infections associated with ESBLs or AmpC-producing Gram-negative bacterial agents. Acquired resistance to carbapenems was not commonly observed until recently [29]. Beta-lactamase-mediated resistance to carbapenems is mostly due to the expression of class A KPC beta-lactamases, susceptible to the inhibition by clavulanic acid, class B metallobeta-lactamases of the IMP, VIM, or NDM series, or OXA-48 beta-lactamase belonging to the class $\mathrm{D}$ beta-lactamases that are not inhibited by clavulanic acid, tazobactam, and 
sulbactam and thus confer on the producing isolates resistance to beta-lactam inhibitor combinations [30,31].

\section{Escherichia coli}

E. coli is the most frequent urinary pathogen in the outpatient setting $[3,5,8]$. Around $70 \%$ of the isolates are resistant to ampicillin due to the production of TEM- 1 broad spectrum beta-lactamase [5]. Furthermore, the resistance to expanded-spectrum cephalosporins is mainly attributed to the production of ESBLs belonging to TEM, SHV, and CTX-M families, and to a lesser extent mediated by plasmid encoded AmpC beta-lactamases [32]. ESBL rates in E. coli range from around 4\% in Europe, 24\% in Africa, to 50\% in Nepal [33,34]. TEM and SHV variants were dominant in the 1990s, whereas CTX-M have been increasing recently all over the world, with the CTX-M-15 variant being widespread around the globe with a resistance phenotype including a high level of resistance to extended-spectrum cephalosporins (ESCs) and ciprofloxacin [35]. There are many reports on this allelic variant in urinary isolates from South America [36,37], Africa [38], and Asia [34]. Other CTX-M allelic variants found among urinary isolates were CTX-M-1, CTX-M-3, CTX-M-14, and CTX-M-27 [39]. Some other ESBLs found in urinary E. coli isolates are SHV-7 and OXA1 [33]. In Africa, TEM-22 outnumbered CTX-M variants among urinary E. coli isolates [33]. The rate of AmpC beta-lactamases reaches 30\% in some geographic areas, with CMY-2 type being the most prevalent [33].

Moreover, a study from Iraq found a prevalence of ESBLs of 7\% among E. coli associated with uncomplicated UTIs of the lower urinary tract, while in the upper urinary tract infections the prevalence was 30\% [40]. In that study, TEM-ESBLs were dominant in both types of infections with rates of $31 \%$ and $65 \%$, respectively, followed by CTX-M $\beta$ lactamases ( $24 \%$ vs. $60 \%$ ), whereas SHV was the least prevalent (28\% vs. $50 \%$ ) [40]. A recent study conducted in Romania demonstrated high resistance rates among uropathogenic $E$. coli with resistance rates of $48 \%$ for ampicillin, $41 \%$ for tetracycline, $24 \%$ for cotrimoxazole, $19 \%$ for amoxicillin-clavulanic acid, $16 \%$ for cefazolin, $15 \%$ for ciprofloxacin, and $15 \%$ for levofloxacin; furthermore, $35 \%$ of the investigated strains were multidrug resistant [41]. This report identified $9.3 \%$ of the uropathogenic isolates as harbouring ESBLs with $42 \%$ being positive for CTX-M beta-lactamases, 38\% for TEM, and 19.7\% for SHV. The majority of isolates possessed various virulence factors such as type 1 fimbriae (93\%), haemolysin D (44\%), A fimbriae (38\%), capsules (32\%), S fimbriae (22\%), and haemolysin A (12\%) [41]. Resistance to fluoroquinoles, as demonstrated in the aforementioned study, is usually attributed to $q n r$ genes ( $q n r A, q n r B, q n r S$ ) that encode Qnr proteins protecting the topoisomerase enzyme. They were found in approximately $30 \%$ of isolates in a recent study by Onanuga et al. [33] from Africa. Moreover, gentamicin resistance was found in $44 \%$ of the ESBL-positive isolates due to the aacC2 gene in the same study [33].

In Croatia, CTX-M ESBLs of group 1 were found to be associated with UTIs in different geographic regions after the year 2000 [42-44]. CTX-M-15 was the dominant type, albeit CTX-M-3 was also found in some isolates [43]. bla СTX-M genes were carried by FIA and $\mathrm{L} / \mathrm{M}$ plasmids (according to the plasmid incompatibility grouping) in the early 1990s, and SHV-2 and SHV-5 were found in UTI isolates of E. coli [45]. They caused urinary tract infections in neonates and young children, and they were associated with specific virulence factors such as resistance to serum bactericidal activity and haemolysin production.

There is a positive correlation between biofilm production and ESBL positivity [46]. Among urinary isolates there were $14 \%$ strong, 17\% moderate, and $22 \%$ weak biofilm producers [46]. In the past, ESBL-positive isolates were identified predominantly in hospital acquired UTIs, but recently a dramatic increase of ESBL positivity was observed among community isolates as well [47]. Previous exposure to cefuroxime was found to be a risk factor [47]. Due to an increasing trend of ESBL-positivity in E. coli and consequential multidrug-resistant phenotypes, guidelines for the management of UTIs were updated. More specifically, fosfomycin and nitrofurantoin are now recommended as first line empirical oral therapy for the treatment of community acquired, uncomplicated UTI [48]. 
E. coli sequence types (STs) are established with the multilocus sequence typing (MLST), and E. coli ST-131 containing CTX-M-15 are mostly of serotype O25:H4; interestingly, the latter serotype was found in clinical urinary specimens and in environmental waters in Sweden, indicating that the urinary tract represents an important pollutant factor for wastewater that comes into the aquatic environment [49]. Among clinical urinary isolates, CTX-M-15 was the dominant type, present in $62 \%$, followed by CTX-M- 14 and CTX-M-27, found in $8.9 \%$ and $6.7 \%$ of the isolates, respectively [49]. The majority of the isolates (33\%) belonged to widespread ST-131 lineage, whereas $14 \%$ belonged to ST-38. Likewise, the B2 phylogenetic group was the most prevalent (44\%) [49].

An increasing trend of multidrug-resistance, mainly due to ESBL production, was observed in E. coli isolated from pregnant woman with limited therapeutic options [50]. Earlier studies carried out in the 1990s found plasmid-mediated, transferable SHV-5 betalactamase conferring high level ceftazidime resistance among urinary E. coli isolates from the United Kingdom, and the isolates possessed additional TEM- $1 \beta$-lactamase [51]. TEM28 was reported in urinary tract $E$. coli isolates in a nursing home in California [52]. Among community isolates, TEM-21 and CTX-M-1 were found to be dominant in France [53]. Spanish reports demonstrated CTX-M-15, CTX-M-14, CTX-M-1, and CTX-M-9 to be the most prevalent in urinary ESBL-positive E. coli $[54,55]$. Those studies have also shown that the $b l a_{\mathrm{CTX}-\mathrm{M}-14}$ gene was preceded by the ISEcp 1 insertion sequence, which plays a significant role in its mobilization and acts as a promotor, increasing expression of the gene [54,55]. Moreover, ESBLs have been reported not only in human medicine, but also in animals. More specifically, E. coli producing SHV-12 was identified in urine of a dog suffering from recurrent UTIs [56].

Inhibitor-resistant TEM (IRT) beta-lactamases were reported among urinary E. coli isolates in Spain. They conferred on producing isolates resistance to amoxicillin/clavulanic acid, ampicillin/sulbactam, and to lesser extent piperacillin/tazobactam. IRT-3 was carried on a transferable $45-\mathrm{kb}$ plasmid [57]. Inhibitor-resistant TEM beta-lactamases are dominant among community acquired infections, which are often treated with $\beta$-lactam/inhibitor combinations [53,57].

Recently, carbapenemase production was reported in urinary isolates of $E$. coli belonging to class A (KPC), class B (VIM, NDM, IMP), and class D (OXA-48), with the latter showing a trend of significant global spread [58]. The production of carbapenemase is usually associated with an extensively drug-resistant phenotype, leaving very few therapeutic options. A recent study from Pakistan showed significant presence of both ESBL and carbapenemase producers, as well as co-existence of ESBL and carbapenemases in the same isolate [59]. In that study, $50 \%$ of isolates were resistant to both imipenem and meropenem, with some isolates expressing the $b l a_{\mathrm{NDM}-1}$ gene [59], which indicates a worrying trend.

\section{Klebsiella pneumoniae}

Resistance to expanded-spectrum cephalosporins in K. pneumoniae is usually mediated by the production of ESBLs belonging to the TEM, SHV, and CTX-M families or plasmidmediated AmpC beta-lactamases, mainly DHA or FOX [28]. The rate of ESBL production in K. pneumoniae is around $40 \%$, depending on the local epidemiology. Very high rates reaching 50\% were observed in urinary isolates in Turkey [60]; nonetheless, carbapenems were shown to possess good activity against ESBL producing isolates. The dominant type is CTX-M-15 found in $80 \%$ of the isolates in Portugal, while the dominant ST found in urinary isolates was ST-1 [61]. Conversely, in Iran SHV-ESBLs were dominant; furthermore, among ESBL-positive organisms, $10 \%$ were hypervirulent, whereas $22 \%$ were found to possess $q n r A$, $q n r B$, and $q n r S$ genes [62]. However, it has to be emphasized that these studies are from quite different years, which has to be taken into account when discussing their findings.

A recent study carried out in Iraq found that $59 \%$ of the isolates obtained from upper urinary tract infections carried $b l a_{\mathrm{ESBL}}$ genes, in contrast to $18 \%$ from the lower urinary tract [40]. The rates of TEM, SHV, and CTX-M beta-lactamases in kidney infections were 
$88 \%, 76 \%$, and $6.4 \%$, respectively. Moreover, $b l a_{\mathrm{TEM}}$ genes were also dominant in lower urinary tract infections $(83 \%)$, followed by bla $_{\mathrm{SHV}}(55 \%)$ and bla $_{\mathrm{CTX}-\mathrm{M}}(6 \%)$ [40].

Earlier studies from the early 1990s identified SHV-2 conferring a high level of cefotaxime resistance among urinary isolates in Germany and the US [63,64]. SHV-5 was reported among urinary isolates in the Netherlands in the early 2000s [65]. The isolates expressed AadB and AadA2 aminoglycoside resistance determinants and had the overexpression of multidrug efflux pumps. Hungarian urinary isolates possessed SHV$2 \mathrm{a}$ and SHV-5 on conjugative 217-kb plasmids [66]. Furthermore, urinary isolates from Poland were shown to possess TEM-48 [67]. The first report on transferable resistance to extended-spectrum cephalosporins in urinary K. pneumoniae isolates originates from 1987 in France [68]. Since molecular identification of resistance genes was not available in this period, the beta-lactamase was designated as TEM-1-like. The outpatient K. pneumoniae isolates in France in the early 2000s were positive for TEM-15, TEM-19, TEM-21, TEM-24, and SHV-4 [53]. Rare types of ESBLs such as VEB-1 were demonstrated in the Far East [69]. Aside from ESBLs, plasmid-mediated AmpC beta-lactamase DHA-1, originating from Morganella morganii, was responsible for resistance to expanded-spectrum cephalosporins in urinary isolates of K. pneumoniae in France [70].

Studies carried out in Croatia demonstrated SHV-2, SHV-2a, and SHV-5 to be associated with UTIs in the 1990s [71,72]. However, a shift to CTX-M of group 1 was demonstrated after 2000, initially within the in-hospital setting [73]. Very soon after that, the dissemination of group 1 CTX-M beta-lactamases was detected among K. pneumoniae in the outpatient setting [74]. Recently, carbapenem resistance emerged in K. pneumoniae isolates (which include UTI isolates) due to the production of carbapenemases of class A (KPC), class B (VIM, IMP, NDM), and class D (OXA-48); in the last decade, OXA-48 has become a dominant type of carbapenemase in K. pneumoniae in Europe and the Middle East [58]. The first carbapenem-resistant urinary isolates of K. pneumoniae were recorded in Croatia in 2012, and they were found to produce VIM-2 and NDM-1 [75]. All metallobeta-lactamase (MBL) isolates showed an extensively drug-resistant (XDR) phenotype, including resistance not only to beta-lactam antibiotics, but also to aminoglycosides and fluoroquinolones. VIM-2 was the dominant carbapenemase among urinary tract isolates in Croatia until 2015 [76], when it was replaced by OXA-48, which rapidly spread in all geographic regions in Croatia and also in other European countries. bla VIM genes were carried by $\mathrm{A} / \mathrm{C}$ and $\mathrm{N}$ plasmids, whereas $\mathrm{L} / \mathrm{M}$ plasmids harboured bla $\mathrm{OXA}-48$ genes [77]. Although OXA-48 does not hydrolyse extended-spectrum cephalosporins, the majority of isolates harboured additional ESBLs, conferring resistance to cephalosporins as well [77].

\section{Pseudomonas aeruginosa}

P. aeruginosa is an important causative agent of urinary tract infections in the hospital setting [78]. It possesses multiple intrinsic and acquired resistance mechanisms, including the overexpression of AmpC and the production of ESBLs and carbapenemases, mostly belonging to class B. Carbapenem resistance in P. aeruginosa is usually mediated by the production of metallo-beta-lactamases of IMP, VIM, GIM, SPM, or NDM series; loss of OprD outer membrane protein; and/or upregulation of MexAB or MexCD efflux pumps [78]. In Mediterranean countries, VIM-2 is the most frequent carbapenemase found in P. aeruginosa, whereas IMP variants predominate in the Far East [79]. Recently, NDM-1 and KPC-2 were found in carbapenem-resistant $P$. aeruginosa $[78,79]$. ESBLs are rare in $P$. aeruginosa, compared to Enterobacteriaceae, and are predominantly of unusual types such as PER, VEB, and IBC families [79]. OXA-type ESBLs were reported among urinary isolates from Egypt, conferring resistance to ceftazidime, cefepime, and aztreonam [80]. Resistance to aminoglycosides is usually due to the production of acetylases, adenylases, and phosphorylases, which modify aminoglycosides and render them inactive, while resistance to fluoroquinolones is mediated by mutations in $\operatorname{parC}$ and gyr $A$ genes $[78,80]$.

A recent study conducted in Iran showed that $8 \%$ of isolates were multidrug resistant [81]. Among the resistant isolates, $31.2 \%$ and $75 \%$ were ESBL and MBL producers, 
respectively. The prevalence of $b l a_{\mathrm{OXA} 10}, b l a_{\mathrm{VIM}}, b l a_{\mathrm{OXA} 48}, b l a_{\mathrm{OXA}-2}$, and $b l a_{\mathrm{CTX}-\mathrm{M}}$ was $100 \%$, $50 \%, 31.2 \%, 25 \%$, and $12.5 \%$. [81]. Furthermore, two isolates (12.5\%) harbored bla $a_{\text {PER }}$ and $b l a_{\mathrm{NDM}}$ genes. Urinary tract isolates showed high diversity of different pulsotypes. Ceftazidime-avibactam and ceftolozane-tazobactam were shown to express high antimicrobial activity against urinary $P$. aeruginosa isolates with only $8 \%$ of resistant isolates, and the isolates resistant to ceftazidime-avibactam and cefotolozane-tazobactam were positive for ESBLs or MBLs [81]. However, PER-1 ESBL was found among urinary P. aeruginosa isolates in northern Italy much earlier [82]. The isolates exhibited a multidrug-resistant phenotype, including resistance to expanded-spectrum cephalosporins, aztreonam, meropenem, aminoglycosides, and ciprofloxacin, and were associated with nosocomial outbreaks. PER-1 was chromosomally encoded and was not transferable. SHV-5 was identified in a nosocomial outbreak involving $P$. aeruginosa from various specimens including urine in Athens in Greece [83]. In addition to expanded-spectrum cephalosporins, the isolates were resistant to aminoglycosides and fluoroquinolones.

Studies carried out in Croatia showed the emergence of VIM-2 among urinary tract isolates in 2004-2005 in Zagreb (i.e., the capital of Croatia) [84]. VIM-2 producing organisms displayed a high level of resistance to all beta-lactam antibiotics (except aztreonam), and also to aminoglycosides and fluoroquinolones. At the same time VIM-2-positive urinary $P$. aeruginosa isolates were identified in the southern region of Croatia; they all belonged to ST-111 and were embedded in class 1 integrons, which also carried aac genes responsible for aminoglycoside resistance and the bla $a_{\mathrm{OXA}-1}$ gene [79]. The dominant role of OprD loss and efflux pump upregulation in the resistance to carbapenems was demonstrated later, as was the lack of acquired carbapenemases [85].

\section{Acinetobacter baumannii}

Carbapenem resistance in $A$. baumannii is due to production of carbapenemases of class $\mathrm{D}(\mathrm{CHDL})$, class $\mathrm{B}$, or rarely class A; moreover, porin loss or upregulation of efflux pumps can contribute to the resistance phenotype [86]. Molecular analysis of carbapenemases in urinary isolates of $A$. baumannii in Croatia revealed the predominance of OXA-24-like CHDL from 2009 to 2011 [87-89], but it was outnumbered by OXA-23-like CHDL in later years [90]. Both OXA-23-like and OXA-24/40-like carbapenemases confer a high level of resistance to carbapenems, and the plasmids encoding CHDL usually contain resistance genes for aminoglycosides and fluoroquinolones [86,90]. The majority of isolates belonged to the widespread International clonal lineage II (IC II). OXA-24/40-like CHDL was also found in urinary A. baumannii isolates from Bosnia and Herzegovina [91], while OXA-58 was reported among urinary isolates from Greece linked to nosocomial outbreaks [92].

\section{Resistance "Snapshot" in Other Notable Gram-Negative Urinary Tract Pathogens}

In P. mirabilis, the most important resistance determinants to expanded-spectrum cephalosporins are ESBLs and pAmpC $[53,93]$. The most prevalent ESBL type in P. mirabilis is TEM-52, which efficiently hydrolyses aztreonam and ceftazime [93]; however, TEM-21 was identified among urinary isolates in France [53]. Among pAmpC, CMY-16 producing P. mirabilis was reported to cause outbreaks in long-term care facilities in Italy and Croatia $[94,95]$. In both reports, the isolates were clonally related and resistant to all $\beta$-lactams except cefepime and carbapenems. Such a trend of cephalosporinase dynamic switch from TEM variants to CTX-M and CMY was demonstrated in a more recent study from Croatia as well [96]. A study from Iraq found TEM ESBLs to be dominant among upper UTIs, with $50 \%$ positive isolates. Only 25\% of the isolates harboured SHV and CTX-M beta-lactamases, respectively [40].

In Enterobacter cloacae (E. cloacae) isolates, a study performed in Croatia identified ESBLs belonging to CTX-M group 1 and derepressed AmpC beta-lactamases to be responsible for resistance to expanded-spectrum cephalosporins in urinary isolates [97]. CTX-M producing organisms harboured additional TEM-1 or SHV-1 beta-lactamases. ESBLs were encoded on highly transferable L/M or A/C plasmids [97]. A first report of NDM-1 in 
Enterobacter aerogenes in Croatia and Europe was also recently published [98]. A study conducted in Austria demonstrated that resistance to expanded-spectrum cephalosporins was mediated by derepressed, partially derepressed, or inducible beta-lactamases. ESBLs were found in only $4 \%$ of the isolates [99]. Urinary ESBL-positive Enterobacter spp. isolates were found to produce CTX-M-10 with high level cefotaxime resistance [31]. VEB-1 (Vietnam extended-spectrum beta-lactamase) was demonstrated among isolates from Thailand [69]. bla $a_{\text {VEB-1 }}$ genes were located in class 1 integrons carrying bla OXA-10 and arr gene cassettes (the latter conferring rifampin resistance) born by self-transferable conjugative plasmids of $200 \mathrm{~kb}$. Similarly, as in E. coli, SHV-12 was demonstrated in Enterobacter spp. urinary isolates from dogs in Australia. In addition to SHV-12, CMY-2 was confirmed in some of the samples [100].

As far as Providencia is concerned, a recent study found CTX-M beta-lactamases of group 1 among urinary $P$. retgerii and P. stuarti isolates from Croatia, resistant to expandedspectrum cephalosporins [101]. These isolates were clonally related and identified during an outbreak in the University Hospital Split. P. stuarti from outpatients in France produced TEM-24 [53].

The data on antimicrobial resistance in urinary isolates of C. freundii, S. marcescens, and $M$. morganii are scarce in the medical literature. A study from Iraq found $11 \%$ of the $C$. freundii isolates from kidney infections to harbour ESBLs when compared to the isolates from the urinary bladder, which were all ESBL negative. In that study, TEM -ESBLs were dominant, followed by CTX-M and SHV-2a [40]. In urinary ESBL-positive S. marcescens and $M$. morganii isolates, a study from France identified TEM-24 as the dominant resistance trait [53].

\section{Laboratory Identification of Resistance Mechanisms as a Prerequisite for Targeted Treatment}

The double disk synergy test [102] and combined disk test with clavulanic acid as a confirmatory method are still pervasively used in a majority of routine laboratories to detect ESBLs in E. coli, K. pneumoniae, and P. mirabilis [103]. The E-test using a gradient of ceftazidime concentrations (alone and combined with clavulanic acid) and Vitek 2 are also used in some laboratories. Carbapenemases are detected by a modified Hodge test [104], CIM test [105], or CarbaNP test $[105,106]$, depending on the laboratory protocols. The modified Hodge test has a high sensitivity in detection of KPC-producing K. pneumoniae and is simple to perform, thus it is often recommended as a screening test [107]; more specifically, a meropenem disk is placed on the Mueller Hinton Agar (MHA) plate, previously seeded with the $0.5 \mathrm{McF}$ arland suspension of the indicator organism E. coli ATCC 25922 [104,108]. The isolates are then inoculated onto the plate in a straight line out from the edge of the disk to the end of the plate. Subsequently, the plates are incubated at $35^{\circ} \mathrm{C}$ overnight and then growth of the indicator strain toward the carbapenem disk is examined [108]. Isolates that allowed growth of the indicator strain up to $3 \mathrm{~mm}$ are recorded as weakly positive, whereas those with growth of more than $3 \mathrm{~mm}$ were labelled positive; conversely, the absence of growth of the indicator strain toward the carbapenem disc is recorded as a negative result [108]. The CIM for the detection of suspected carbapenemase production, originally developed for Enterobacterales, is used for Acinetobacter and Pseudomonas as well [105]. Briefly, a meropenem $10 \mu \mathrm{g}$ disc is incubated for two hours in a thick suspension of the tested strains, removed with a loop, and then placed on MHA inoculated with a susceptible E. coli indicator strain (ATCC 29522), with subsequent overnight incubation at $35{ }^{\circ} \mathrm{C}$ [105]. If a strain is a carbapenemase producer, the meropenem in the susceptibility disc is inactivated, allowing uninhibited growth of the susceptible indicator strain. The test is considered positive if the inhibition zone around the meropenem disk is less than $14 \mathrm{~mm}$ or if there are colonies growing inside of the inhibition zone [105]. Currently, the RESIST-4 O.K.N.V chromatographic method is available for detection of major carbapenemase types such as KPC, NDM, VIM, and OXA-48 [109]. It is easy to use, does not necessitate special equipment, and provides results in a very short amount of time with high sensitivity. 
Chromogenic plates to detect certain types of carbapenemases are also available, but their main drawback is a rather high cost [110].

Inhibitor-based tests with EDTA and phenyloboronic acid (PBA) are used to distinguish between MBLs inhibited by metal chelators and KPC inhibited by PBA. OXA-48 is detected using temocillin disks. The genes conferring resistance to beta-lactams, including broad spectrum and extended-spectrum beta-lactamases $\left(b l a_{\mathrm{SHV}}, b l a_{\mathrm{TEM}}, b l a_{\mathrm{CTX}-\mathrm{M}}, b l a_{\mathrm{OXA}-9}\right.$, bla $_{\text {OXA-1 }}$ and bla $a_{\text {PER-1 }}$ ) [82,111-113], plasmid-mediated AmpC $\beta$-lactamases [114], class A $\left(b l a_{\mathrm{KPC}}, b l a_{\mathrm{SME}}, b l a_{\mathrm{IMI}}, b l a_{\mathrm{NMC}}\right)$, class B carbapenemases $\left(b l_{\mathrm{VIM}}, b l a_{\mathrm{IMP}}\right.$ and $\left.b l a_{\mathrm{NDM}}\right)$, carbapenem hydrolyzing oxacillinases (bla $\mathrm{OXA}_{-48}$-like) [115], and fluoroquinolone resistance genes ( $q n r A, q n r B, q n r S)$ [116], can be determined by PCR, but those tests are usually only performed for research purposes.

The implementation of rapid diagnostic techniques and the development of valid prediction tools to identify ESBL infections early definitely aid in reducing the delay of the introduction of antimicrobial therapy, as well as in avoiding inadequate administration of broad-spectrum antibiotics for patients with susceptible microorganisms [117]. Consequently, several different approaches to accelerate the diagnosis of ESBLs have been explored recently, which include the detection of $b l a_{\mathrm{ESBL}}$ genes by the microarray method [118] or by utilizing matrix-assisted laser desorption/ionization-time of flight (MALDI-TOF) [119,120]. Nonetheless, the aforementioned methods necessitate prior expertise and can be expensive; on top of that, as evidenced by this review, cephalosporin resistance may be caused by a plethora of genetic mechanisms that are difficult to detect by a single test. Hence, it is not likely that these methods will be introduced as a routine approach in most clinical microbiology laboratories. Regardless of the diagnostic approach pursued, the choice of the UTI treatment depends on the type of infection, causative agents, in vitro susceptibility, age of the patient, and the general condition of the patient in question.

\section{Conclusions}

This review clearly showed that there is a high variety of different resistance mechanisms among urinary isolates (summarized in Table 1), while the prevalence patterns of different resistance mechanisms are highly dependent on the local epidemiology. Although this leaves us with an interesting global resistance map, it has to be taken into account that studies were conducted in different time periods. However, the fact remains that due to an increase in the prevalence of multidrug or extensively drug-resistant strains among urinary tract Gram-negative pathogens, as well as the lack of new antibiotics, the therapeutic options are getting severely limited. Therefore, there should not only be increased efforts and research projects focused on innovations in the field of antimicrobial stewardship in ambulatory settings, but also on its impact on the emergence and spread of ESBL-producing microorganisms in community settings.

Table 1. A literature-informed summary of resistance mechanisms described in Gram-negative urinary isolates.

\begin{tabular}{|c|c|c|c|c|c|c|}
\hline & \multirow[b]{2}{*}{ ESBL } & \multirow[b]{2}{*}{ AmpC } & \multirow[b]{2}{*}{ Carbapenemases } & \multirow{2}{*}{$\begin{array}{c}\text { Aminoglycoside } \\
\text { Resistance } \\
\text { Mechanisms }\end{array}$} & \multirow{2}{*}{$\begin{array}{c}\text { Fluoroquinolone } \\
\text { Resistance } \\
\text { Mechanisms }\end{array}$} & \multirow{2}{*}{$\begin{array}{c}\text { References } \\
\text { (Sorted } \\
\text { Alphabetically) }\end{array}$} \\
\hline & & & & & & \\
\hline Escherichia Coli & $\begin{array}{c}\text { CTX-M-1 } \\
\text { CTX-M-3 } \\
\text { CTX-M-14 } \\
\text { CTX-M-9 } \\
\text { CTX-M-15 } \\
\text { CTX-M-27 } \\
\text { CTX-M-30 } \\
\text { SHV-7 } \\
\text { OXA-1 } \\
\text { TEM-21 } \\
\text { TEM-22 } \\
\text { TEM-28 } \\
\text { IRT-3 } \\
\text { SHV-12 }\end{array}$ & CMY-2 & $\begin{array}{c}\text { KPC } \\
\text { VIM } \\
\text { IMP } \\
\text { OXA-48 } \\
\text { Efflux pumps }\end{array}$ & $\operatorname{aacC2}$ & $\begin{array}{l}q n r A, q n r B, q n r S, \\
\text { mutations in gyrA } \\
\text { and parC genes }\end{array}$ & $\begin{array}{c}\text { Arpin, 2003 } \\
\text { Blazquez, 1993 } \\
\text { Bohnert, 2006 } \\
\text { Bou, 2002 } \\
\text { Bradford, 1996 } \\
\text { Kim, 2020 } \\
\text { Onanuga, 2019 } \\
\text { Rodrigez-Bano, 2004 } \\
\text { Teshager, 2000 } \\
\text { Yasufuku, 2011 }\end{array}$ \\
\hline
\end{tabular}


Table 1. Cont.

\begin{tabular}{|c|c|c|c|c|c|c|}
\hline & \multirow[b]{2}{*}{ ESBL } & \multirow[b]{2}{*}{ AmpC } & \multirow[b]{2}{*}{ Carbapenemases } & \multirow{2}{*}{$\begin{array}{c}\text { Aminoglycoside } \\
\text { Resistance } \\
\text { Mechanisms }\end{array}$} & \multirow{2}{*}{$\begin{array}{c}\text { Fluoroquinolone } \\
\text { Resistance } \\
\text { Mechanisms }\end{array}$} & \multirow{2}{*}{$\begin{array}{c}\text { References } \\
\text { (Sorted } \\
\text { Alphabetically) }\end{array}$} \\
\hline & & & & & & \\
\hline $\begin{array}{c}\text { Klebsiella } \\
\text { Pneumoniae }\end{array}$ & $\begin{array}{c}\text { CTX-M-15 } \\
\text { SHV-2 } \\
\text { SHV-2a } \\
\text { SHV-5 } \\
\text { TEM-15 } \\
\text { TEM-19 } \\
\text { TEM-21 } \\
\text { TEM-24 } \\
\text { TEM-48 }\end{array}$ & $\begin{array}{l}\text { DHA-1 } \\
\text { FOX } \\
\text { CMY-2 }\end{array}$ & $\begin{array}{c}\text { KPC } \\
\text { VIM } \\
\text { IMP } \\
\text { OXA-48 }\end{array}$ & $\begin{array}{c}16 \mathrm{~S} \text { rRNA } \\
\text { methylases: } r m t A \text {, } \\
\text { rmt } B, \text { arm } A \\
\text { aad } B \\
\operatorname{aad} A 2\end{array}$ & $\begin{array}{l}q n r A, q n r B, q n r S, \\
\text { mutations in gyrA } \\
\text { and parC genes }\end{array}$ & $\begin{array}{c}\text { Arpin, 2003 } \\
\text { Bedenić, 1998 } \\
\text { Bedenić, 2001 } \\
\text { Bedenić, 2010 } \\
\text { Damjanova, 2007 } \\
\text { Damjanova, 2008 } \\
\text { Gniadkowski, 1998 } \\
\text { Gruteke, 2003 } \\
\text { M'Zali, 1995 } \\
\text { Podbielski, 1991 } \\
\text { Thomson, 1991 } \\
\text { Vedet, 2006 } \\
\text { Zujić-Atalić, 2014 }\end{array}$ \\
\hline Enterobacter spp. & $\begin{array}{l}\text { CTX-M-15 } \\
\text { CTX-M-10 } \\
\text { VEB-1 }\end{array}$ & $\begin{array}{l}\text { Derepressed } \\
\text { AmpC }\end{array}$ & VIM-1 & & & $\begin{array}{c}\text { Apfalter, } 2002 \\
\text { Franolić-Kukina, } 2016 \\
\text { Girlich, } 2001\end{array}$ \\
\hline Proteus spp. & TEM-52 & CMY-16 & & & & $\begin{array}{l}\text { Bedenić, } 2016 \\
\text { Sardelić, } 2010\end{array}$ \\
\hline $\begin{array}{l}\text { Klebsiella } \\
\text { Aerogenes }\end{array}$ & $\begin{array}{l}\text { TEM-3 } \\
\text { TEM-24 }\end{array}$ & & & & & Arpin, 2003 \\
\hline Citrobacter spp. & $\begin{array}{l}\text { CTX-M-2 } \\
\text { CTX-M-14 } \\
\text { CTX-M-15 } \\
\text { SHV-12 }\end{array}$ & & & & $\begin{array}{c}\text { qnrB4 } \\
\text { qnrS } \\
\text { AAc6-Ib-cr }\end{array}$ & Kanamori, 2011 \\
\hline $\begin{array}{l}\text { Acinetobacter } \\
\text { Baumannii }\end{array}$ & & & $\begin{array}{l}\text { OXA-23 } \\
\text { OXA-24 } \\
\text { OXA-58 }\end{array}$ & $\begin{array}{c}\text { 16S rRNA } \\
\text { methylases: } \operatorname{armA} \text {, } \\
\text { rmtB }\end{array}$ & $\begin{array}{l}\text { mutations in gyr } A \\
\text { and parC genes }\end{array}$ & $\begin{array}{c}\text { Franolić-Kukina, } 2011 \\
\text { Garneau-Tsodikova, } \\
2016 \\
\text { Ladavac, } 2015 \\
\text { Pournaras, 2006 } \\
\text { Vranić-Ladavac, } 2014\end{array}$ \\
\hline $\begin{array}{c}\text { Pseudomonas } \\
\text { Aeruginosa }\end{array}$ & $\begin{array}{l}\text { OXA-10 } \\
\text { OXA-17 } \\
\text { SHV }-5\end{array}$ & & VIM-2 & $\begin{array}{c}16 \mathrm{~S} \text { rRN } \\
\text { Amethylases: } \\
\operatorname{arm} A, r m t A, r m t B, \\
\operatorname{rmt} D 1, \text { rmt } \mathrm{r} \\
\text { aacC6 }\end{array}$ & $\begin{array}{l}\text { mutations in gyr } A \\
\text { and parC genes }\end{array}$ & $\begin{array}{c}\text { Bošnjak, } 2010 \\
\text { Bubonja-Šonje, } 2015 \\
\text { Garneau-Tsodikova, } \\
\text { 2016 } \\
\text { Poirel, 2004 } \\
\text { Sardelić, 2012 } \\
\text { Sorour, 2008 }\end{array}$ \\
\hline
\end{tabular}

Author Contributions: Conceptualization, T.M., B.B.; writing-original draft preparation, B.B.; writing-review and editing, T.M.; supervision, B.B. All authors have read and agreed to the published version of the manuscript.

Funding: This study received no external funding.

Institutional Review Board Statement: Not applicable. This is the review article not involving human or animal subjects. The permission from Ethical Committee was not necessary.

Informed Consent Statement: Not applicable. This is not a clinical study involving patients.

Data Availability Statement: Not applicable.

Conflicts of Interest: The authors declare no conflict of interest.

\section{References}

1. Öztürk, R.; Murt, A. Epidemiology of urological infections: A global burden. World J. Urol. 2020, 38, 2669-2679. [CrossRef]

2. Kaur, R.; Kaur, R. Symptoms, risk factors, diagnosis and treatment of urinary tract infections. Postgrad. Med. J. 2020. [CrossRef]

3. McLellan, L.K.; Hunstad, D.A. Urinary Tract Infection: Pathogenesis and Outlook. Trends Mol. Med. 2016, 22, 946-957. [CrossRef]

4. Meštrović, T.; Matijašić, M.; Perić, M.; Čipčić Paljetak, H.; Barešić, A.; Verbanac, D. The Role of Gut, Vaginal, and Urinary Microbiome in Urinary Tract Infections: From Bench to Bedside. Diagnostics 2020, 11, 7. [CrossRef]

5. Cavallo, J.D.; Tenke, P. Urinary tract infections. In European Manual of Clinical Microbiology, 1st ed.; Cornaglia, G., Courcol, R., Herrmann, J.L., Kahlmeter, G., Peigue-Lafeuille, H., Vila, J., Eds.; SFM-ESCMID: Paris, France; Basel, Switzerland, 2012; pp. 133-143. 
6. Guglietta, A. Recurrent urinary tract infections in women: Risk factors, etiology, pathogenesis and prophylaxis. Future Microbiol. 2017, 12, 239-246. [CrossRef]

7. Zhao, F.; Yang, H.; Bi, D.; Khaledi, A.; Qiao, M. A systematic review and meta-analysis of antibiotic resistance patterns, and the correlation between biofilm formation with virulence factors in uropathogenic $E$. coli isolated from urinary tract infections. Microb. Pathog. 2020, 144, 104196. [CrossRef]

8. Gupta, K.; Grigoryan, L.; Trautner, B. Urinary Tract Infection. Ann. Intern. Med. 2017, 167, ITC49-ITC64. [CrossRef]

9. Š̌kerk, V.; Andrašević, A.T.; Andrašević, S.; Sušić, E.; Džepina, A.M.; Mađarić, V.; Milutinović, S.; Krhen, I.; Perić, L.; Bagatin, J.; et al. ISKRA guidelines on antimicrobial treatment and prophylaxis of urinary tract infections-Croatian national guidelines. Lijec. Vjesn. 2009, 131, 105-118.

10. Leung, A.K.C.; Wong, A.H.C.; Leung, A.A.M.; Hon, K.L. Urinary Tract Infection in Children. Recent. Pat. Inflamm. Allergy Drug. Discov. 2019, 13, 2-18. [CrossRef]

11. Schmiemann, G.; Kniehl, E.; Gebhardt, K.; Matejczyk, M.M.; Hummers-Pradier, E. The diagnosis of urinary tract infection: A systematic review. Dtsch. Arztebl. Int. 2010, 107, 361-367. [CrossRef]

12. Ternes, B.; Wagenlehner, F.M.E. Guideline-based treatment of urinary tract infections. Urologe A 2020, 59, 550-558. [CrossRef]

13. Flores-Mireles, A.L.; Walker, J.N.; Caparon, M.; Hultgren, S.J. Urinary tract infections: Epidemiology, mechanisms of infection and treatment options. Nat. Rev. Microbiol. 2015, 13, 269-284. [CrossRef]

14. Khoshnood, S.; Heidary, M.; Mirnejad, R.; Bahramian, A.; Sedighi, M.; Mirzaei, H. Drug-resistant gram-negative uropathogens: A review. Biomed. Pharmacother. 2017, 94, 982-994. [CrossRef]

15. Kline, K.A.; Lewis, A.L. Gram-Positive Uropathogens, Polymicrobial Urinary Tract Infection, and the Emerging Microbiota of the Urinary Tract. Microbiol. Spectr. 2016, 4. [CrossRef]

16. Kranz, J.; Wagenlehner, F.M.E.; Schneidewind, L. Complicated urinary tract infections. Urologe A 2020, 59, 1480-1485. [CrossRef]

17. Kliebe, C.; Nies, B.; Meyer, J.; Tolxdorf-Neutzling, R.; Wiedemann, B. Evolution of plasmid encoded resistance to broad-spectrum cephalosporins. Antimicrob. Agents Chemother. 1985, 28, 302-327. [CrossRef]

18. Bradford, P.A. Extended-spectrum beta-lactamases in the 21st Century: Characterization, Epidemiology, and Detection of This Important Resistance Threat. Clin. Microbiol. Rev. 2001, 14, 933-951. [CrossRef]

19. Jacoby, G.A.; Munoz-Price, L.S. The new ß-lactamases. N. Engl. J. Med. 2005, 352, 380-391. [CrossRef]

20. Płusa, T.; Konieczny, R.; Baranowska, A.; Szymczak, Z. The growing resistance of bacterial strains to antibiotics. Pol. Merkur. Lekarski. 2019, 47, 106-110.

21. Doi, Y.; Iovleva, A.; Bonomo, R.A. The ecology of extended-spectrum $\beta$-lactamases (ESBLs) in the developed world. J. Travel Med. 2017, 24, S44-S51. [CrossRef]

22. Bonnet, R. Growing group of extended-spectrum $\beta$-lactamases: The CTX-M enzymes. Antimicrob. Agents Chemother. 2004, 48, 1-14. [CrossRef]

23. Rossolini, G.M.; D'Andrea, M.M.; Mugnaioli, C. The spread of CTX-M-type extended-spectrum $\beta$-lactamases. Clin. Microbiol. Infect. 2008, 14, 33-41. [CrossRef]

24. Gniadkowski, M.; Palucha, A.; Grzesiowski, P.; Hryniewicz, W. Outbreak of ceftazidime-resistant Klebsiella pneumoniae in Warsaw, Poland; Clonal spread of the TEM-47 Extended-spectrum $\beta$-lactamase (ESBL)-producing strain and transfer of a plasmid carrying the SHV-5 like ESBL-encoding gene. Antimicrob. Agents Chemother. 1998, 42, 3079-3085.

25. Shannon, K.; Stapleton, P.; Xiang, X.; Johnson, A.; Beattie, H.; El Bakri, F.; Cookson, B.; French, G. Extended-spectrum $\beta$-lactamaseproducing Klebsiella pneumoniae strains causing nosocomial outbreak of infection in the United Kingdom. J. Clin. Microbiol. 1998, $36,3105-3110$.

26. Silva, J.; Gatica, R.; Aguilar, C.; Beccera, Z.; Garza-Ramos, U.; Velazquez, M.; Miranda, G.; Leanos, B.; Solorzano, F.; Echaniz, G. Outbreak of infections with extended-spectrum $\beta$-lactamase producing Klebsiella pneumoniae in a Mexican Hospital. J. Clin. Microbiol. 2001, 39, 3193-3196. [CrossRef]

27. Essack, S.Y. Treatment options for extended-spectrum $\beta$-lactamase producers. FEMS Microbiol. Lett. 2000, 190, 181-184. [CrossRef]

28. Jacoby, G.A. AmpC $\beta$-lactamases. J. Clin. Microbiol. 2009, 22, 161-182. [CrossRef]

29. Elshamy, A.A.; Aboshanab, K.M. A review on bacterial resistance to carbapenems: Epidemiology, detection and treatment options. Future Sci. OA 2020, 6, FSO438. [CrossRef]

30. Queenan, A.M.; Bush, K. Carbapenemases: The versatile $\beta$-lactamases. Clin. Microbiol. Rev. 2007, 20, 440-458. [CrossRef]

31. Canton, R.; Akova, M.; Carmeli, Y.; Giske, C.G.; Glupczynski, Y.; Gniadkowski, M.; Livermore, D.M.; Miriagou, V.; Naas, T.; Rossolini, G.M.; et al. Rapid evolution and spread of carbapenemases among Enterobacteriaceae in Europe. Clin. Microbiol. Infect. 2012, 18, 413-431. [CrossRef]

32. Peirano, G.; Pitout, J.D.D. Extended-Spectrum $\beta$-Lactamase-Producing Enterobacteriaceae: Update on Molecular Epidemiology and Treatment Options. Drugs 2019, 79, 1529-1541. [CrossRef]

33. Onanuga, A.; Mahindroo, J.; Singh, S.; Taneja, N. Phenotypic and molecular characterization of antimicrobial resistant Escherichia coli from urinary tract infections in Port-Harcourt, Nigeria. Pan Afr. Med. J. 2019, 34, 144. [CrossRef]

34. Thapa Shrestha, U.; Shrestha, S.; Adhikari, N.; Rijal, K.R.; Shrestha, B.; Adhikari, B.; Banjara, M.R.; Ghimire, P. Plasmid Profiling and Occurrence of $\beta$-Lactamase Enzymes in Multidrug-Resistant Uropathogenic Escherichia coli in Kathmandu, Nepal. Infect. Drug Resist. 2020, 13, 1905-1917. [CrossRef] 
35. Chong, Y.; Shimoda, S.; Shimono, N. Current epidemiology, genetic evolution and clinical impact of extended-spectrum $\beta$ lactamase-producing Escherichia coli and Klebsiella pneumoniae. Infect. Genet. Evol. 2018, 61, 185-188. [CrossRef]

36. Millán, Y.; Hernández, E.; Millán, B.; Araque, M. Distribution of phylogenetic groups and virulence factors in CTX-M-15 $\beta$-lactamase-producing uropathogenic Escherichia coli strains isolated from patients in the community of Mérida, Venezuela. Rev. Argent. Microbiol. 2014, 46, 175-181. [CrossRef]

37. Millán, Y.; Araque, M.; Ramírez, A. Distribution of phylogenetic groups, virulence factors and antimicrobial susceptibility in strains of uropathogenic Escherichia coli. Rev. Chilena. Infectol. 2020, 37, 117-123. [CrossRef]

38. Biset, S.; Moges, F.; Endalamaw, D.; Eshetie, S. Multi-drug resistant and extended-spectrum $\beta$-lactamases producing bacterial uropathogens among pregnant women in Northwest Ethiopia. Ann. Clin. Microbiol. Antimicrob. 2020, 19, 25. [CrossRef]

39. Tayh, G.; Al Laham, N.; Ben Yahia, H.; Ben Sallem, R.; Elottol, A.E.; Ben Slama, K. Extended-Spectrum $\beta$-Lactamases among Enterobacteriaceae Isolated from Urinary Tract Infections in Gaza Strip, Palestine. Biomed. Res. Int. 2019, 2019, 4041801. [CrossRef]

40. Majeed, H.T.; Aljanabi, A.J. Antibiotic susceptibility patterns and prevalence of some extended-spectrum $\beta$-lactamase genes in Gram-negative bacteria isolated from patients infected with urinary tract infections in Al-Najaf City, Iraq. Avicenna J. Med. Biotechnol. 2019, 11, 192-201.

41. Cristea, V.C.; Gheorghe, I.; Czobor Barbu, I.; Popa, L.I.; Ispas, B.; Grigore, G.A.; Bucatariu, I.; Popa, G.L.; Angelescu, M.C.; Velican, A.; et al. Snapshot of Phylogenetic Groups, Virulence, and Resistance Markers in Escherichia coli Uropathogenic Strains Isolated from Outpatients with Urinary Tract Infections in Bucharest, Romania. Biomed. Res. Int. 2019, 2019, 5712371. [CrossRef]

42. Tonkić, M.; Bedenić, B.; Goić-Barišić, I.; Katić, S.; Kalenić, S.; Kaufmann, M.E.; Woodford, N.; Punda-Polić, V. First report of CTX-M extended-spectrum beta-lactamase-producing isolates from croatia. J. Chemother. 2007, 19, 97-100. [CrossRef]

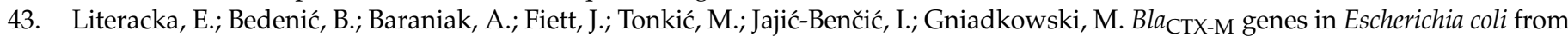
Croatian hospitals are located in new $\left(b_{\mathrm{CTX}-\mathrm{M}-3}\right)$ and widely spread $\left(\right.$ bla $_{\mathrm{CTX}-\mathrm{M}-3 \mathrm{a}}$, bla $\left._{\mathrm{CTX}-\mathrm{M}-15}\right)$ genetic structures. Antimicrob. Agents Chemother. 2009, 53, 1630-1635. [CrossRef]

44. Krilanović, M.; Tomić-Paradžik, M.; Meštrović, T.; Beader, N.; Herljević, Z.; Conzemius, R.; Barišić, I.; Vraneš, J.; Elveđi-Gašparović, V.; Bedenić, B. Extended-spectrum beta-lactamases and plasmid diversity in urinary isolates of Escherichia coli in Croatia: A nation-wide, multicentric, retrospective study. Folia Microbiol. (Praha) 2020, 65, 649-667. [CrossRef]

45. Bedenić, B.; Vraneš, J.; Hofmann-Thiel, S.; Tonkić, M.; Novak, A.; Bučević-Popović, V.; Hoffmann, H. Characterization of the extended-spectrum beta-lactamases and determination of the virulence factors of uropathogenic Escherichia coli strains isolated from children. Wien. Klin. Wochenschr. 2012, 124, 504-515. [CrossRef]

46. Shrestha, R.; Khanal, S.; Poudel, P.; Khadayat, K.; Ghaju, S.; Bhandari, A.; Lekhak, S.; Pant, N.D.; Sharma, M.; Marasini, B.P. Extended spectrum $\beta$-lactamase producing uropathogenic Escherichia coli and the correlation of biofilm with antibiotics resistance in Nepal. Ann. Clin. Microbiol. Antimicrob. 2019, 18, 42. [CrossRef]

47. Calbo, E.; Romani, V.; Xercavins, M.; Gomez, L.; Vidal, C.G.; Quintana, S.; Vila, J.; Gara, J. Risk factors for community-onset urinary tract infections due to Escherichia coli harbouring extended-spectrum $\beta$-lactamases. J. Antimicrob. Chemother. 2006, 57, 780-783. [CrossRef]

48. Meier, S.; Weber, R.; Zbinden, R.; Ruef, C.; Hasse, B. Extended-spectrum beta-lactamase producing Gram-negative pathogens in community-acquired urinary tract infections; an increasing challenge for antimicrobial therapy. Infection 2011, 39, 333-340. [CrossRef]

49. Fagerström, A.; Mölling, P.; Khan, F.A.; Sundqvist, M.; Jass, J.; Söderquist, B. Comparative distribution of extended-spectrum betalactamase-producing Escherichia coli from urine infections and environmental waters. PLoS ONE 2019, 14, e0224861. [CrossRef]

50. Moradi, Y.; Eshrati, B.; Motevalian, S.A.; Majidpour, A.; Baradaran, H.R. A systematic review and meta-analysis on the prevalence of Escherichia coli and extended-spectrum $\beta$-lactamase-producing Escherichia coli in pregnant women. Arch. Gynecol. Obstet. 2021, 303, 363-379. [CrossRef]

51. M'Zali, F.H.; Heritage, J.; Gascoyne-Binzi, D.M.; Denton, M.; Todd, N.J.; Hawkey, P.M. Transcontinental importation into the UK of Escherichia coli expressing a plasmid-mediated AmpC-type beta-lactamase exposed during an outbreak of SHV-5 extended-spectrum beta-lactamase in a Leeds hospital. J. Antimicrob. Chemother. 1997, 40, 823-831. [CrossRef] [PubMed]

52. Bradford, P.A.; Jacobus, N.V.; Bhachech, N.; Bush, K. TEM-28 from an Escherichia coli clinical isolate is a member of the His-164 family of TEM-1 extended-spectrum beta-lactamases. Antimicrob. Agents Chemother. 1996, 40, 260-262. [CrossRef]

53. Arpin, C.; Dubois, V.; Coulange, L.; André, C.; Fischer, I.; Noury, P.; Grobost, F.; Brochet, J.P.; Jullin, J.; Dutilh, B.; et al. Extendedspectrum beta-lactamase-producing Enterobacteriaceae in community and private health care centers. Antimicrob. Agents Chemother. 2003, 47, 3506-3514. [CrossRef]

54. Bou, G.; Cartelle, M.; Tomas, M.; Canle, D.; Molina, F.; Moure, R.; Eiros, J.M.; Guerrero, A. Identification and broad dissemination of the CTX-M-14 beta-lactamase in different Escherichia coli strains in the northwest area of Spain. J. Clin. Microbiol. 2002, 40, 4030-4036. [CrossRef]

55. Rodríguez-Baño, J.; Navarro, M.D.; Romero, L.; Martínez-Martínez, L.; Muniain, M.A.; Perea, E.J.; Pérez-Cano, R.; Pascual, A. Epidemiology and clinical features of infections caused by extended-spectrum beta-lactamase-producing Escherichia coli in nonhospitalized patients. J. Clin. Microbiol. 2004, 42, 1089-1094. [CrossRef]

56. Teshager, T.; Domínguez, L.; Moreno, M.A.; Saénz, Y.; Torres, C.; Cardeñosa, S. Isolation of an SHV-12 beta-lactamase-producing Escherichia coli strain from a dog with recurrent urinary tract infections. Antimicrob. Agents Chemother. 2000, 44, 3483-3484. [CrossRef] 
57. Blazquez, J.; Baquero, M.R.; Canton, R.; Alos, I.; Baquero, F. Characterization of a new TEM-type beta-lactamase resistant to clavulanate, sulbactam, and tazobactam in a clinical isolate of Escherichia coli. Antimicrob. Agents Chemother. 1993, 37, $2059-2063$. [CrossRef]

58. Pitout, J.D.D.; Peirano, G.; Kock, M.M.; Strydom, K.A.; Matsumura, Y. The Global Ascendency of OXA-48-Type Carbapenemases. Clin. Microbiol. Rev. 2019, 33, e00102-19. [CrossRef]

59. Irfan, S.; Azhar, A.; Bashir, A.; Ahmed, S.; Haque, A. High frequency of simultaneous presence of ESBL and carbapenemase producers among nosocomial coliform isolates in Faisalabad, Pakistan. Pak. J. Med. Sci. 2021, 37, 34-39. [CrossRef]

60. Aladag, M.O.; Uysal, A.; Dundar, N.; Durak, Y.; Gunes, E. Characterization of Klebsiella pneumoniae strains isolated from urinary tract infections: Detection of ESBL characteristics, antibiotic susceptibility and RAPD genotyping. Pol. J. Microbiol. 2013, 62, 401-409.

61. Marques, C.; Menezes, J.; Belas, A.; Aboim, C.; Cavaco-Silva, P.; Trigueiro, G.; Telo Gama, L.; Pomba, C. Klebsiella pneumoniae causing urinary tract infections in companion animals and humans: Population structure, antimicrobial resistance and virulence genes. J. Antimicrob. Chemother. 2019, 74, 594-602. [CrossRef]

62. Taraghian, A.; Nasr Esfahani, B.; Moghim, S.; Fazeli, H. Characterization of Hypervirulent Extended-Spectrum $\beta$-LactamaseProducing Klebsiella pneumoniae Among Urinary Tract Infections: The First Report from Iran. Infect. Drug Resist. 2020, 13, 3103-3111. [CrossRef]

63. Thomson, K.S.; Sanders, C.C.; Washington, J.A., 2nd. High-level resistance to cefotaxime and ceftazidime in Klebsiella pneumoniae isolates from Cleveland, Ohio. Antimicrob. Agents Chemother. 1991, 35, 1001-1003. [CrossRef]

64. Podbielski, A.; Schönling, J.; Melzer, B.; Warnatz, K.; Leusch, H.G. Molecular characterization of a new plasmid-encoded SHV-type beta-lactamase (SHV-2 variant) conferring high-level cefotaxime resistance upon Klebsiella pneumoniae. J. Gen. Microbiol. 1991, 137, 569-578. [CrossRef]

65. Gruteke, P.; Goessens, W.; Van Gils, J.; Peerbooms, P.; Lemmens-Den Toom, N.; Van Santen-Verheuvel, M.; Van Belkum, A.; Verbrugh, H. Patterns of resistance associated with integrons, the extended-spectrum beta-lactamase SHV-5 gene, and a multidrug efflux pump of Klebsiella pneumoniae causing a nosocomial outbreak. J. Clin. Microbiol. 2003, 41, 1161-1166. [CrossRef]

66. Damjanova, I.; Tóth, A.; Pászti, J.; Jakab, M.; Milch, H.; Bauernfeind, A.; Füzi, M. Epidemiology of SHV-type beta-lactamaseproducing Klebsiella spp. from outbreaks in five geographically distant Hungarian neonatal intensive care units: Widespread dissemination of epidemic R-plasmids. Int. J. Antimicrob. Agents 2007, 29, 665-671. [CrossRef]

67. Gniadkowski, M.; Schneider, I.; Jungwirth, R.; Hryniewicz, W.; Bauernfeind, A. Ceftazidime-resistant Enterobacteriaceae isolates from three Polish hospitals: Identification of three novel TEM- and SHV-5-type extended-spectrum beta-lactamases. Antimicrob. Agents Chemother. 1998, 42, 514-520. [CrossRef]

68. Brun-Buisson, C.; Legrand, P.; Philippon, A.; Montravers, F.; Ansquer, M.; Duval, J. Transferable enzymatic resistance to third-generation cephalosporins during nosocomial outbreak of multiresistant Klebsiella pneumoniae. Lancet 1987, 2, 302-306. [CrossRef]

69. Girlich, D.; Poirel, L.; Leelaporn, A.; Karim, A.; Tribuddharat, C.; Fennewald, M.; Nordmann, P. Molecular epidemiology of the integron-located VEB-1 extended-spectrum beta-lactamase in nosocomial enterobacterial isolates in Bangkok, Thailand. J. Clin. Microbiol. 2001, 39, 175-182. [CrossRef]

70. Verdet, C.; Benzerara, Y.; Gautier, V.; Adam, O.; Ould-Hocine, Z.; Arlet, G. Emergence of DHA-1-producing Klebsiella spp. in the Parisian region: Genetic organization of the $a m p C$ and $a m p R$ genes originating from Morganella morganii. Antimicrob. Agents Chemother. 2006, 50, 607-617. [CrossRef]

71. Bedenić, B.; Žagar, Ž. Extended-spectrum beta-lactamases in clinical isolates of Klebsiella pneumoniae from Zagreb, Croatia. J. Chemother. 1998, 10, 449-459. [CrossRef]

72. Bedenić, B.; Randegger, C.; Stobberingh, E.; Haechler, H. Molecular epidemiology of extended-spectrum beta-lactamases from Klebsiella pneumoniae strains isolated in Zagreb, Croatia. Eur. J. Clin. Microbiol. Infect. Dis. 2001, 20, 505-508. [CrossRef]

73. Vranić-Ladavac, M.; Bošnjak, Z.; Beader, N.; Barišić, N.; Kalenić, S.; Bedenić, B. Clonal spread of CTX-M producing Klebsiella pneumoniae in Croatian hospital. J. Med. Microbiol. 2010, 59, 1069-1078. [CrossRef]

74. Bedenić, B.; Vraneš, J.; Bošnjak, Z.; Marijan, T.; Mlinarić-Džepina, A.; Kukovec, T.; Anušić, M.; Beader, N.; Barl, P.; Leskovar, V.; et al. Emergence of CTX-M group 1 extended-spectrum $\beta$-lactamase-producing Klebsiella pneumoniae strains in the community. Med. Glas. (Zenica) 2010, 7, 32-39.

75. Zujić-Atalić, V.; Bedenić, B.; Kocsis, E.; Mazzariol, A.; Sardelić, S.; Barišić, M.; Plečko, V.; Bošnjak, Z.; Mijač, M.; Jajić, I.; et al. Diversity of carbapenemases in clinical isolates of Enterobacteriaceae in Croatia-The results of the multicenter study. Clin. Microbiol. Infect. 2014, 20, O894-O903. [CrossRef]

76. Bedenić, B.; Sardelić, S.; Luxner, J.; Bošnjak, Z.; Varda-Brkić, D.; Lukić-Grlić, A.; Mareković, I.; Frančula-Zaninović, S.; Krilanović, M.; Šijak, D.; et al. Molecular characterization of class B carbapenemases in advanced stage of dissemination and emergence of class D carbapenemases in Enterobacteriaceae from Croatia. Infect. Genetic. Evol. 2016, 43, 74-82. [CrossRef]

77. Bedenić, B.; Slade, M.; Starčević, L.Ž.; Sardelić, S.; Vranić-Ladavac, M.; Benčić, A.; Zujić Atalić, V.; Bogdan, M.; Bubonja-Šonje, M.; Tomić-Paradžik, M.; et al. Epidemic spread of OXA-48 beta-lactamase in Croatia. J. Med. Microbiol. 2018, 67, 1031-1034. [CrossRef]

78. Behzadi, P.; Baráth, Z.; Gajdács, M. It's Not Easy Being Green: A Narrative Review on the Microbiology, Virulence and Therapeutic Prospects of Multidrug-Resistant Pseudomonas aeruginosa. Antibiotics 2021, 10, 42. [CrossRef] 
79. Sardelić, S.; Bedenić, B.; Colinon-Dupuich, C.; Orhanović, S.; Bošnjak, Z.; Plečko, V.; Cournoyer, B.; Rossolini, G.M. Infrequent finding of metallo- $\beta$-lactamase VIM-2 in carbapenem-resistant Pseudomonas aeruginosa from Croatia. Antimicrob. Agents Chemother. 2012, 56, 2746-2749. [CrossRef]

80. Sorour, A.E.; Wali, I.E.; El-Hodaky, K. OXA-type beta-lactamases among extended-spectrum-cephalosporins non-susceptible Pseudomonas aeruginosa isolates collected from a large teaching hospital in Cairo. Egypt. J. Med. Microbiol. 2008, 17, 565-572.

81. Rahimzadeh, M.; Habibi, M.; Bouzari, S.; Karam, M.R.A. First study of antimicrobial activity of ceftazidime-avibactam and ceftolozone-tazobactam against Pseudomonas aeruginosa isolated from patients with urinary tract infections in Tehran, Iran. Infect. Drug Resist. 2020, 13, 533-541. [CrossRef]

82. Pagani, L.; Mantengoli, E.; Migliavacca, R.; Nucleo, E.; Pollini, S.; Spalla, M.; Daturi, R.; Romero, E.; Rossolini, G.M. Multifocal detection of multidrug-resistant Pseudomonas aeruginosa producing PER-1 extended-spectrum $\beta$-lactamase in Northern Italy. J. Clin. Microbiol. 2004, 42, 2523-2529. [CrossRef]

83. Poirel, L.; Lebessi, E.; Castro, M.; Fèvre, C.; Foustoukou, M.; Nordmann, P. Nosocomial outbreak of extended-spectrum betalactamase SHV-5-producing isolates of Pseudomonas aeruginosa in Athens, Greece. Antimicrob. Agents Chemother. 2004, 48, 2277-2279. [CrossRef]

84. Bošnjak, Z.; Bedenić, B.; Mazzariol, A.; Jarža-Davila, N.; Šuto, S.; Kalenić, S. VIM-2 beta-lactamase in Pseudomonas aeruginosa isolates from Zagreb, Croatia. Scand. J. Infect. Dis. 2010, 42, 193-197. [CrossRef]

85. Bubonja-Šonje, M.; Matovina, M.; Škrobonja, I.; Bedenić, B.; Abram, M. Mechanisms of carbapenem-resistance in multidrugresistant clinical isolates of Pseudomonas aeruginosa from a Croatian Hospital. Microb. Drug Resist. 2015, 21, 261-269. [CrossRef]

86. Ramirez, M.S.; Bonomo, R.A.; Tolmasky, M.E. Carbapenemases: Transforming Acinetobacter baumannii into a Yet More Dangerous Menace. Biomolecules 2020, 10, 720. [CrossRef]

87. Franolić-Kukina, I.; Bedenić, B.; Budimir, A.; Herljević, Z.; Vraneš, J.; Higgins, P. Clonal spread of carbapenem-resistant OXA-72 positive Acinetobacter baumannii in a Croatian university hospital. Int. J. Infect. Dis. 2011, 15, e706-e709. [CrossRef]

88. Goić-Barišić, I.; Towner, K.J.; Kovačić, A.; Sisko-Kraljević, K.; Tonkić, M.; Novak, A.; Punda-Polić, V. Outbreak in Croatia caused by a new carbapenem-resistant clone of Acinetobacter baumannii producing OXA-72 carbapenemase. J. Hosp. Infect. 2011, 77, 368-369. [CrossRef]

89. Vranić-Ladavac, M.; Bedenić, B.; Minandri, F.; Ištok, M.; Frančula-Zaninović, S.; Ladavac, R.; Visca, P. Carbapenem-resistance and acquired class D carbapenemases in Acinetobacter baumannii from Croatia 2009-2010. Eur. J. Clin. Microbiol. Infect. Dis. 2014, 33, 471-478. [CrossRef]

90. Ladavac, R.; Bedenić, B.; Vranić-Ladavac, M.; Barišić, N.; Karčić, N.; Pompe, K.; Ferenčić, A.; Stojanović, A.; Seifert, H.; Katić, S.; et al. Emergence of different Acinetobacter baumannii clones in a Croatian hospital and correlation with antibiotic susceptibility. J. Glob. Antimicrob. Resist. 2017, 10, 213-218. [CrossRef]

91. Petrović, T.; Uzunović, S.; Barišić, I.; Luxner, J.; Grisold, A.; Zarfel, G.; Ibrahimagić, A.; Jakovac, S.; Slaćanac, D.; Bedenić, B. Arrival of carbapenem-hydrolyzing-oxacillinases in Acinetobacter baumannii in Bosnia and Herzegovina. Infect. Genet. Evol. 2018, 58, 192-198. [CrossRef]

92. Pournaras, S.; Markogiannakis, A.; Ikonomidis, A.; Kondyli, L.; Bethimouti, K.; Maniatis, A.N.; Legakis, N.J.; Tsakris, A. Outbreak of multiple clones of imipenem-resistant Acinetobacter baumannii isolates expressing OXA-58 carbapenemase in an intensive care unit. J. Antimicrob. Chemother. 2006, 57, 557-561. [CrossRef]

93. Sardelić, S.; Bedenić, B.; Šijak, D.; Colinon, C.; Kalenić, S. Emergence of Proteus mirabilis isolates producing TEM-52 extendedspectrum $\beta$-lactamase in Croatia. Chemotherapy 2010, 56, 208-213. [CrossRef]

94. Migliavacca, R.; Nucleo, E.; D’Andrea, M.M.; Spalla, M.; Giani, T.; Pagani, L. Acquired AmpC type beta-lactamases: An emerging problem in Italian long-term care and rehabilitation facilities. New Microbiol. 2007, 30, 295-298.

95. Bedenić, B.; Firis, N.; Elveđi-Gašparović, V.; Krilanović, M.; Matanović, K.; Štimac, I.; Luxner, J.; Vraneš, J.; Meštrović, T.; Zarfel, G.; et al. Emergence of multidrug-resistant Proteus mirabilis in a long-term care facility in Croatia. Wien. Klin. Wochenschr. 2016, 128, 404-413. [CrossRef]

96. Meštrović, T.; Lukić-Grlić, A.; Bogdan, M.; Bandić-Pavlović, D.; Cavrić, G.; Drenjančević, D.; Sreter, B.K.; Benčić, A.; Sardelić, S.; Bedenić, B. Cephalosporinases in Proteus mirabilis isolates from long-term care facilities and the community. Acta Med. Croat. 2018, 3, 285-294.

97. Franolić-Kukina, I.; Sardelić, S.; Beader, N.; Varda-Brkić, D.; Firis, N.; Čačić, M.; Šijak, D.; Frančula-Zaninović, S.; ElveđiGašparović, V.; Mareković, I.; et al. Evolution of beta-lactam antibiotic resistance in Enterobacter spp. in Croatia. Lijec. Vjesn. 2016, $138,240-249$.

98. Franolić, I.; Bedenić, B.; Beader, N.; Lukić-Grlić, A.; Mihaljević, S.; Bielen, L.; Zarfel, G.; Meštrović, T. NDM-1-producing Enterobacter aerogenes isolated from a patient with a JJ ureteric stent in situ. CEN Case Rep. 2019, 8, 38-41. [CrossRef]

99. Apfalter, P.; Assadian, O.; Daxböck, F.; Hirschl, A.M.; Rotter, M.L.; Makristathis, A. Extended double disc synergy testing reveals a low prevalence of extended-spectrum beta-lactamases in Enterobacter spp. in Vienna, Austria. J. Antimicrob. Chemother. 2007, 59, 854-859. [CrossRef]

100. Sidjabat, H.E.; Hanson, N.D.; Smith-Moland, E.; Bell, J.M.; Gibson, J.S.; Filippich, L.J.; Trott, D.J. Identification of plasmid-mediated extended-spectrum and AmpC beta-lactamases in Enterobacter spp. isolated from dogs. J. Med. Microbiol. 2007, 56, 426-434. [CrossRef] 
101. Barl, P.; Bedenić, B.; Sardelić, S.; Uzunović-Kamberović, S.; Vraneš, J.; Plečko, V. Spread of CTX-M-15 positive Providencia spp. causing urinary tract infections at the University Hospital Split in Croatia. Med. Glas. (Zenica) 2012, 9, 317-324.

102. Jarlier, V.; Nicolas, M.H.; Fournier, G.; Philippon, A. Extended broad-spectrum beta-lactamases conferring transferable resistance to newer beta-lactam agents in Enterobacteriaceae: Hospital prevalence and susceptibility patterns. Rev. Infect. Dis. 1988, 10, 867-878. [CrossRef]

103. Clinical and Laboratory Standards Institute (CLSI). Performance Standards for Antimicrobial Susceptibility Testing; CLSI M100 2020 Edition, M100-S; CLSI: Wayne, PA, USA, 2020.

104. Lee, K.; Lim, Y.S.; Yong, D.; Yum, J.H.; Chong, Y. Evaluation of the Hodge test and the imipenem-EDTA-double-disk synergy test for differentiating metallo- $\beta$-lactamase-producing isolates of Pseudomonas spp. and Acinetobacter spp. J. Clin. Microbiol. 2005, 41, 4623-4629. [CrossRef]

105. van der Zwaluw, K.; de Haan, A.; Pluister, G.N.; Bootsma, H.J.; de Neeling, A.J.; Schouls, L.M. The carbapenem-inacitvation method (CIM) a simple and low-cost alternative for the Carba NP test to assess phenotypic carbapenemase activity in Gramnegative rods. PLoS ONE 2015, 10, e0123690. [CrossRef]

106. Simon, M.; Richert, K.; Pfennigwerth, N.; Pfeifer, Y.; Reischl, U.; Gatermann, S.; Gessner, A.; Jantsch, J. Carbapenemase detection using the $\beta$-CARBA test: Influence of test conditions on performance and comparison with the RAPIDEC CarbaNP assay. $J$. Microbiol. Methods 2018, 147, 17-19. [CrossRef]

107. Meštrović, T.; Bedenić, B. eComment. Diagnostic intricacies and fortuitous treatment approaches for carbapenem-resistant Klebsiella pneumoniae. Interact. Cardiovasc. Thorac. Surg. 2016, 23, 768. [CrossRef]

108. Pasteran, F.; Gonzalez, L.; Albornoz, E.; Bahr, G.; Vila, A.; Corso, A. Triton Hodge Test: Improved Protocol for Modified Hodge Test for Enhanced Detection of NDM and Other Carbapenemase Producers. J. Clin. Microbiol. 2015, 54, 640-649. [CrossRef]

109. Cointe, A.; Bonacorsi, S.; Truong, J.; Hobson, C.; Doit, C.; Monjault, A.; Bidet, P.; Birgy, A. Detection of Carbapenemase-Producing Enterobacteriaceae in Positive Blood Culture Using an Immunochromatographic RESIST-4 O.K.N.V. Assay. Antimicrob. Agents Chemother. 2018, 62. [CrossRef]

110. Wilkinson, K.; Winstanley, T.; Lanyon, C.; Cummings, S.; Raza, M.; Perry, J. Comparison of Four Chromogenic Culture Media for Carbapenemase-Producing Enterobacteriaceae. J. Clin. Microbiol. 2012, 50, 3102-3104. [CrossRef]

111. Arlet, G.; Brami, G.; Decre, D.; Flippo, A.; Gaillot, O.; Lagrange, P.H.; Phillipon, A. Molecular characterization by PCR restriction fragment polymorphism of TEM $\beta$-lactamases. FEMS Microbiol. Lett. 1995, 134, 203-208. [CrossRef]

112. Nüesch-Inderbinen, M.T.; Hächler, H.; Kayser, F.H. Detection of genes coding for extended-spectrum SHV $\beta$-lactamases in clinical isolates by a molecular genetic method, and comparison with the E test. Eur. J. Clin. Microbiol. Infect. Dis. 1996, 15, 398-402. [CrossRef]

113. Woodford, N.; Ward, M.E.; Kaufmann, M.E.; Turton, J.; Fagan, E.J.; James, D.; Johnson, A.P.; Pike, R.; Warner, M.; Cheasty, T.; et al. Community and hospital spread of Escherichia coli producing CTX-M extended-spectrum $\beta$-lactamases in the UK. J. Antimicrob. Chemother. 2004, 54, 735-743. [CrossRef]

114. Perez-Perez, F.J.; Hanson, N.D. Detection of plasmid-mediated AmpC $\beta$-lactamase genes in clinical isolates by using multiplex PCR. J. Clin. Microbiol. 2002, 40, 2153-2162. [CrossRef]

115. Poirel, L.; Walsh, T.R.; Cuveiller, V.; Nordman, P. Multiplex PCR for detection of acquired carbapenemases genes. Diagn. Microbiol. Infect. Dis. 2011, 70, 119-125. [CrossRef]

116. Robicsek, A.; Jacoby, G.A.; Hooper, D.C. The worldwide emergence of plasmid-mediated quinolone resistance. Lancet Infect. Dis. 2006, 6, 629-640. [CrossRef]

117. Tal Jasper, R.; Coyle, J.R.; Katz, D.E.; Marchaim, D. The complex epidemiology of extended-spectrum $\beta$-lactamase-producing Enterobacteriaceae. Future Microbiol. 2015, 10, 819-839. [CrossRef]

118. Naas, T.; Cuzon, G.; Truong, H.; Bernabeu, S.; Nordmann, P. Evaluation of a DNA microarray, the check-points ESBL/KPC array, for rapid detection of TEM, SHV, and CTX-M extended-spectrum beta-lactamases and KPC carbapenemases. Antimicrob. Agents Chemother. 2010, 54, 3086-3092. [CrossRef]

119. Oviaño, M.; Fernández, B.; Fernández, A.; Barba, M.J.; Mouriño, C.; Bou, G. Rapid detection of Enterobacteriaceae producing extended spectrum beta-lactamases directly from positive blood cultures by matrix-assisted laser desorption ionization-time of flight mass spectrometry. Clin. Microbiol. Infect. 2014, 20, 1146-1157. [CrossRef]

120. Ota, Y.; Furuhashi, K.; Hirai, N.; Ishikawa, J.; Nagura, O.; Yamanaka, K.; Maekawa, M. Evaluation of MBT STAR-Cepha and MBT STAR-Carba kits for the detection of extended-spectrum $\beta$-lactamases and carbapenemase producing microorganisms using matrix-assisted laser desorption/ionization time-of-flight mass spectrometry. J. Microbiol. Methods 2021, 183, 106166. [CrossRef] 